\title{
POTENSI LIMBAH KULIT JERUK NIPIS (Citrus auronfolia) SEBAGAI INHIBITOR TIROSINASE
}

\author{
Siti Hindun ${ }^{1}$, Taofik Rusdiana ${ }^{1}$, Marline Abdasah ${ }^{1}$, Reti Hindritiani $^{2}$ \\ ${ }^{1}$ Fakultas Farmasi Universitas Padjadjaran, Jawa Barat, Indonesia \\ ${ }^{2}$ Fakultas Kedokteran Universitas Padjadjaran, Bandung, Indonesia
}

\begin{abstract}
ABSTRAK
Hiperpigmentasi merupakan kelainan kulit wajah yang umum terjadi, terutama karena adanya peningkatan melanogenesis, dengan gambaran berupa warna kulit menjadi hitam atau coklat kehitaman. Kelainan ini terdapat pada beberapa macam penyakit kulit diantaranya melasma, melanoderma paska inflamasi, lentigo solaris dan freckles. Salah satu prinsip penanganan hiperpigmentasi yaitu menghambat sintesis melanin yang dapat dilakukan dengan menggunakan agen depigmentasi yang mekanisme kerjanya menghambat aktivitas enzim tirosinase. Penelitian ini bertujuan untuk menguji potensi kulit jeruk nipis sebagai inhibitor tirosinase. Kulit jeruk nipis diektraksi dengan etanol $96 \%$, identifikasi flavonoid, menghitung flavonoid total, kemudian diuji inhibisi tirosinase menggunakan instrumen microplate reader (ELISA). Hasil penelitian ekstrak kulit jeruk mengandung flavonid, dengan total flavonid totalnya $0,667 \% \mathrm{~b} / \mathrm{b}$ dan inhibition concentration (IC) ${ }_{50} 42,11 \mathrm{mg} / \mathrm{mL}$, Kulit jeruk berpotensi sebagai inhibisi tirosinase.
\end{abstract}

Kata kunci: Citrus auronfolia, Hiperpigmentasi, $\mathrm{IC}_{50}$, Tirosinase

\section{POTENCY OF LEMON PEEL (Citrus auronfolia) WASTE AS TIROSINASE INHIBITOR}

\begin{abstract}
Hyperpigmentation is a common skin disorder, mainly due to an increase in melanogenesis, with the appearance of skin color to black or dark brown. The disorder is present in several skin diseases such as melasma, post-inflammatory melanoderma, solaris lentigo and freckles. One of the principles of hyperpigmentation is to inhibit melanin synthesis that can be done by using depigmentation agent whose mechanism of action inhibits the activity of tyrosinase enzymes. This study aims to test the potential of lime peel as a tyrosinase inhibitor. Lemon peel was extracted with $96 \%$ ethanol, flavonoid identification, total flavonoid count, then tested inhibition of tyrosinase using microplate reader (ELISA) instrument. The results of citrus skin extract studies contain flavonid, with total flavonid total of $0.667 \% \mathrm{w} / \mathrm{w}$ and inhibition concentration (IC) $5042.11 \mathrm{mg} / \mathrm{mL}$, orange peel potency as inhibition of tyrosinase.
\end{abstract}

Kata Kunci: Citrus auronfolia, Hyperpigmentation, $\mathrm{IC}_{50}$, Tirosinase

\section{Pendahuluan}

Melanin merupakan zat yang memberikan warna coklat atau coklat kehitaman pada kulit, berperan sebagai pelindung kulit terhadap paparan radiasi ultra violet (UV). ${ }^{1}$ Proses pembentukan senyawa melanin (melanogenesis) terjadi dengan bantuan biokatalis terutama enzim tirosinase. Enzim tirosinase mengkatalisis dua reaksi utama dalam biosintesis melanin, yaitu hidroksilasi L-tirosin menjadi L-dopa dan oksidasi L-dopa menjadi dopakuinon. Senyawa dopakuinon mempunyai kereaktifan yang sangat tinggi dan dapat dipolimerisasi secara spontan membentuk 
melanin. ${ }^{2}$ Pembentukan melanin dapat meningkat bila aktivitas enzim tirosinase meningkat yang terutama karena adanya pajanan sinar UV. Peningkatan sintesis melanin menyebabkan hiperpigmentasi. ${ }^{3}$

Pengobatan hiperpigmentasi yang telah banyak dikembangkan sebagai agen depigmentasi yaitu menginhibisi enzim tirosinase. ${ }^{4}$ Agen depigmentasi yang sering digunakan yaitu hidrokuinon, namun penggunaan jangka panjang dapat menimbulkan iritasi, rebound phenomenon dan okronosis. Kojic acid menimbulkan alergi dan memiliki sifat mutagen. ${ }^{5}$ Berdasarkan hal tersebut, maka perlu dicari agen-agen depigmentasi kulit lain yang bersifat alami dengan efek samping kecil. ${ }^{5}$ Indonesia telah dikenal sebagai negara pemilik kekayaan alam yang berlimpah. Kekayaan alam saat ini telah dikembangkan dalam upaya pemanfaatan tanaman sebagai obat dan kosmetik. Salah satu tanaman yang dapat dikembangkan sebagai obat dan kosmetik adalah jeruk nipis (Citrus aurantifolia).

Jeruk nipis adalah sejenis tanaman perdu yang banyak tumbuh dan dikembangkan di Indonesia. Selain daerah penyebarannya yang sangat luas, jeruk ini juga dapat berbuah terus-menerus sepanjang tahun. Jeruk nipis juga merupakan salah satu tanaman toga yang di gunakan oleh masyarakat, baik untuk bumbu masakan, obat-obatan, dan minuman segar. Pemanfaatan buah jeruk sebagai obat diantaranya sebagai penambah nafsu makan, penurun panas (antipireutik), diare, menguruskan badan, antiinflamasi, antibakteri dan antioksidan. ${ }^{6}$ Kulit jeruknya telah diteliti berperan sebagai antioksidan $\mathrm{IC}_{50} 54,458 \mu \mathrm{g} / \mathrm{ml} .^{7}$

Kulit jeruk nipis dapat diolah untuk mendapatkan kandungan pektin dan flavonoid. Flavonoid adalah zat metabolit sekunder pada jeruk nipis yang memiliki konsentrasi paling tinggi pada bagian kulitnya. ${ }^{8}$ Flavonoid merupakan salah satu zat metabolit sekunder yang terdapat pada jeruk dan kulit jeruk yang berperan sebagai antioksidan, penghambat enzim tirosinase dan juga bekerja pada bagian akhir dari jalur oksidatif melanogenesis. ${ }^{9,10,11}$ Selain itu, beberapa jenis flavonoid seperti hesperidin, naringin, neohesperidin dan nobeletin telah terbukti in vitro dapat menghambat enzim tirosinase. ${ }^{12,13}$

Penelitian ini bertujuan untuk mengetahui efektivitas bahan alam yang dapat digunakan sebagai inhibitor tirosinase khususnya kulit jeruk nipis.

\section{Metode}

Uji efektivitas in vitro dilaksanakan di Pusat Studi Biofarmaka Lembaga Penelitian dan Pengabdian Masyarakat Institus Pertanian Bogor.

Ekstrak kulit jeruk nipis (Citrus auronfolia), etanol $96 \%$ (brataco), DMSO (dimetil sulfoksida) (brataco), akuades, bufer fosfat ph 6.5, L-tirosin, L-DOPA, enzim tirosinase (Sigma 333 unit $/ \mathrm{ml}$ dalam bufer fosfat).

Jeruk nipis diperoleh dari daerah Lembang Bandung Jawa Barat, kemudian dilakukan determinasi di Herbarium Bandungense Sekolah Ilmu dan Teknologi Hayati Institut Teknologi Bandung.

Instrumen yang digunakan adalah spektrofotometer UV-Vis, multiplate well reader (ELISA), multiwell plates, eppendorf microcentrifuge tube, oven, tanur listrik, vorteks, sonikator, inkubator, eksikator, corong buchner, hot plate, nyala bunsen, neraca analitik, rotavapor putar, tabung reaksi, penjepit kayu, gelas erlenmayer, gelas piala, pipet volumetrik, pipet mikro, pipet dot.

Kulit jeruk nipis yang telah dikumpulkan disortir dan dibersihkan kemudian di keringkan dengan cara diangin-anginkan. Sampel yang telah kering diserbuk dengan menggunakan blender, serbuk yang dihasilkan diayak menggunakan ayakan mesh 60 hingga diperoleh serbuk yang halus dan seragam. Hasilnya dimasukan kedalam wadah tertutup.

Metode ektraksi yang digunakan adalah metode maserasi menggunakan 
pelarut etanol $96 \%$. Serbuk simplisia kulit jeruk nipis ditimbang sebanyak 500 gram kemudian dimasukan kedalam maserator yang bagian dasarnya telah dilapisi kapas, kemudian dimasukan pelarut etanol $96 \%$ kedalam maserator hingga simplisia tersebut terendam seluruhnya. Diamkan selama $3 \times 24$ jam, dan setiap 24 jam pelarut diganti dengan pelarut yang baru hingga filtrat yang dihasilkan jernih. Hasil ekstraksi yang diperoleh dipekatkan dengan menggunakan alat vacuum rotary evaporator dilanjutkan dengan water bath. $^{14}$

Sampel dalam tabung reaksi dicampur dengan serbuk magnesium dan ditetesi asam klorida $2 \mathrm{~N}$. Campuran tersebut dipanaskan di atas penangas air selama 30 menit lalu disaring. Filtrat ditambahkan amil alkohol lalu dikocok kuat-kuat. Terbentuknya warna kuning hingga merah yang dapat ditarik dengan amil alkohol menunjukkan adanya flavonoid.

Penentuan kadar flavonoid dilakukan dengan spektrofotometri menggunakan reagen alumunim klorida. Sebanyak $2 \mathrm{~mL}$ larutan ekstrak dengan konsentrasi 50 $\mu \mathrm{g} / \mathrm{mL}$, di tambahkan dengan $2 \mathrm{~mL}$ alumunium klorida $2 \%$ yang telah dilarutkan dengan etanol, kemudian divorteks selama 20 menit, inkubasi campuran larutan selama 24 menit. Ukur absorban pada $415 \mathrm{~nm}$. Buat perhitungan rata-rata 3 kali pengukuran dan kandungan flavonoid dinyatakan dengan kesetaraan pembanding baku. ${ }^{14}$

Ekstrak kulit jeruk nipis dilarutkan di dalam DMSO (dimetil sulfoksida) pada konsentrasi akhir $20 \mu \mathrm{g} / \mathrm{ml}$. Larutan ekstrak tersebut kemudian didilusi pada $600 \mu \mathrm{g} / \mathrm{ml}$ didalam $50 \mathrm{mM}$ buffer fosfat $(\mathrm{pH} 6,5)$. Ekstrak tersebut diuji pada tingkat konsentrasi 5, 10, 20, 30, 40 dan 50 $\mathrm{mg} / \mathrm{mL}$. Asam kojak sebagai kontrol positif di uji pada konsentrasi 0,$1563 ; 0,3125$; 0,$625 ; 1,25 ; 2,5$ dan $5 \mathrm{mg} / \mathrm{mL}$. Didalam pelat tetes 96 sumur. Sebanyak $70 \mu 1$ dari masing-masing ekstrak pengenceran ini ditambahkan dengan $30 \mu \mathrm{l}$ enzim tirosinase (Sigma 333 unit $/ \mathrm{ml}$ dalam buffer fosfat $\mathrm{pH}$
6,5), setelah itu dilakukan inkubasi pada suhu kamar selama 5 menit. Kemudian ditambahkan $110 \mu \mathrm{l}$ substrat $(2 \mathrm{mM}$ Ltirosin atau $12 \mathrm{mM}$ L-DOPA) dalam sumur multi-well plate yang sudah ditentukan, larutan tersebut diinkubasi selama 30 menit pada suhu kamar. Larutan tersebut diukur dengan menggunakan multi well plate reader (ELISA) pada panjang gelombang $492 \mathrm{~nm}$, hal ini bertujuan untuk menentukan persen inhibisi dan nilai konsentrasi hambatan $50 \%\left(\mathrm{IC}_{50}\right) .{ }^{15}$

Penentuan persentase inhibisi ditentukan dengan cara membandingkan absorbansi sampel tanpa penambahan ekstrak dan sampel dengan penambahan ekstrak. Pengukuran persentase aktivitas inhibisi dapat dirumuskan ${ }^{4}$ :

$$
\% \text { inhibisi }=[(\mathrm{A}-\mathrm{B}) / \mathrm{A}] \times 100 \%
$$

Keterangan:

A: absorbansi blanko (tanpa sampel)

B:absorbansi sampel (penambahan sampel)

Nilai $\mathrm{IC}_{50}$ diperoleh dari persamaan regresi linier antara \% inhibisi (sumbuy) dan konsentrasi ekstrak (sumbu $\mathrm{x}$ ), persamaan regresi linier dapat dirumuskan sebagai berikut:

Keterangan:

$$
\mathrm{Y}=\mathrm{a}+\mathrm{bx}
$$

Y : variabel dependen

$\mathrm{X}$ : variabel independen

A : konstanta

B : koefisien regresi

\section{Hasil dan Pembahasan}

Ekstraksi yang dilakukan yaitu ekstraksi dingin dengan cara maserasi, metode ini merupakan metode yang mudah, murah dan efektif untuk menghindari kerusakan zat aktif yang termolabil. Pelarut ekstraksi yang digunakan yaitu etanol $96 \%$ karena pelarut ini merupakan pelarut universal yang dapat menarik hampir seluruh metabolit sekunder, baik yang bersifat polar, semi polar maupun non polar, juga memiliki kandungan air yang 
kecil sehingga mempercepat proses evaporasi dan waterbath serta terhindar dari tumbuhnya jamur.

Sampel dalam tabung reaksi setelah dicampur dengan serbuk magnesium dan ditetesi asam klorida 2 N. kemudian campuran tersebut dipanaskan di atas penangas air selama 30 menit lalu disaring. Filtrat ditambahkan amil alkohol lalu dikocok kuat-kuat, hasilnya terbentuknya warna kuning hingga merah hal tersebut menunjukan ekstrak kulit jeruk mengandung flavonoid. Dapat dilihat pada gambar 1.

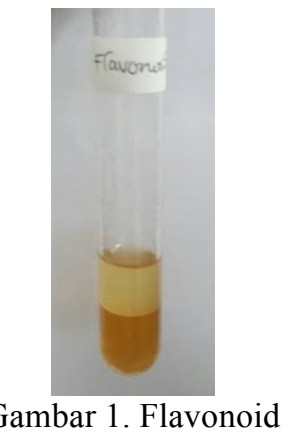

Selanjutnya ekstrak kulit jeruk nipis dihitung flavonoid total dengan cara memasukan nilai absorbansi pada kurva standar kuersetin dengan persamaan kurva yaitu $\mathrm{y}=0,0706 \mathrm{x}-0,0465$ sehingga hasil dari besar flavonoid pada ekstrak kulit jeruk nipis yaitu sebesar $0,667 \% \mathrm{~b} / \mathrm{b} \mathrm{mg} / \mathrm{kg}$. kandungan flavonoid pada sampel tersebut kecil, karena kemungkinan proses preparasi sampel mengalami pemanasan, sehingga kadar dari senyawa flavonoid berkurang. Menurut Lusivera tahun 2002 mengatakan proses pemanasan ini dapat mengakibatkan penurunan kadar total flavonoid sebesar $15-78 \%$.

Enzim tirosinase merupakan suatu glikoprotein yang terletak pada membran melanosom, dan dapat juga berdomain didalam melanosom, transmembran, dan di dalam sitoplasma sel melanosit yang

Dari Persamaan tersebut diperoleh IC50 kulit jeruk nipis yaitu $42,11 \mathrm{mg} / \mathrm{mL}$. Nilai $\mathrm{IC}_{50}$ menentukan tinggi rendahnya ekstrak kulit jeruk nipis sebagai inhibitor tirosinase untuk penghambat pembentukan melanin. Semakin kecil nilai $\mathrm{IC}_{50}$ maka berperan dalam mengkatalisis konversi Ltirosin menjadi L-DOPA dan oksidasi LDOPA menjadi dopakuinon dan oksidasi 5,6 Dihidrosiindol menjadi Indol-6,6 Kuinon selanjutnya membentuk melanin. Enzim tirosinase berperan dalam reaksi pigmentasi kulit atau perubahan warna kulit menjadi lebih coklat. Senyawa yang dapat menghambat proses pembentukan melanin yaitu inhibitor tirosinase, mekanisme kerjanya mereduksi bahan yang dapat menyebabkan oksidasi dopakuinon dan bekerja secara kompetitif dan non kompetitif dengan subbstrat tirosinase yaitu L-tirosin dan L-DOPA serta secara spesifik akan berikatan kovalen dengan enzim tirosinase sehingga enzim menjadi tidak aktif selama reaksi katalik berlangsung. ${ }^{3}$ Inhibitor tirosinase banyak digunakan dalam prodak kosmetik dan farmasi sebagai penghambat produksi melanin berlebih pada lapisan epidermis dan membuat kulit tampak lebih cerah. ${ }^{16}$

Pengujian aktivitas tirosinase dilakukan untuk mengetahui ada tidaknya inhibisi senyawa bioaktif yang terdapat pada ektrak kulit jeruk nipis. Aktivitas inhibisi tirosinase ditunjukan dengan nilai $\mathrm{IC}_{50}$ yaitu konsentrasi yang dibutuhkan dalam menghambat $50 \%$ aktivitas tirosintirosinase menggunakan instrumen microplate reader (ELISA).

Pengujian dilakukan dengan cara pengenceran ekstrak pada konsentrasi 5 $\mathrm{mg}, 10 \mathrm{mg}, 20 \mathrm{mg}, 30 \mathrm{mg}, 40 \mathrm{mg}$ dan 50 mg. Hasil pengujiannya dapat dilihat Tabel 1.

Setelah penentuan persentase inhibisi, selanjutnya penentuan nilai $\mathrm{IC}_{50}$. Penentuan $\mathrm{IC}_{50}$ dengan cara dibuat kurva hubungan konsentrasi inhibitor yaitu sampel (ekstrak kulit jeruk nipis) masukan kedalam persamaan $\mathrm{y}=85,929 \ln (\mathrm{x})-271,4$, seperti yang terdapat pada gambar 2 .

semakin berpotensi senyawa tersebut sebagai inhibitor tirosinase. Tirosinase merupakan enzim mono-oksigenase yang berperan sebagai katalisator pada reaksi hidrosilaksi monofenol menjadi bentuk difenol (monofenolase) dan oksidasi 
difenol menjadi kuinon (difenolase). Tirosinase memiliki peranan penting dalam pembentukan melanin selama proses melanogenesis karena kemampuannya menghidroksilasi L-tirosin (monofenol) menjadi L-dopa (difenol) dan mengoksidasi L-dopa menjadi dopakuinon (senyawa kuinon). Dopakuinon yang terbentuk akan bereaksi secara spontan membentuk dopakrom. Peran tirosinase dalam proses melanogenesis terjadi karena tirosinase memiliki gugus tembaga $(\mathrm{Cu})$ yang merupakan active site yang dapat berkaitan dengan substrat pada proses pembentukan melanin. ${ }^{16} \mathrm{IC}_{50}$ yang diperoleh sebesar $42,11 \mathrm{mg} / \mathrm{ml}$ menunjukan bahwa ekstrak kulit jeruk berpotensi sebagai inhibisi tirosinase.

\section{Kesimpulan}

Kulit jeruk nipis memiliki kandungan flavonoid, total flavonoid $0,667 \% \mathrm{~b} / \mathrm{b}$, dan $\mathrm{IC}_{50} 42,11 \mathrm{mg} / \mathrm{mL}$, berpotensi sebagai pencerah kulit.

\section{Saran}

Ekstrak kulit jeruk nipis perlu dilakukan proses pemurnian lebih lanjut agar diperoleh senyawa yang lebih aktif sebagai inhibitor tirosinase, dan perlu dilakukan penelitian lebih lanjut tentang aktifitas penghambatan tirosinase ekstrak kulit jeruk nipis dengan substrat selain tirosinase.

Tabel 1 Aktivitas penghambatan enzim tirosinase (\%)

\begin{tabular}{ccc}
\hline \multirow{2}{*}{ Sampel } & Konsentrasi $(\mathrm{mg} / \mathrm{g})$ & \% Inhibisi tirosinase \\
& & \\
\hline & 50 & 67,9 \\
Ekstrak kulit jeruk nipis & 40 & 40,0 \\
& 30 & 23,3 \\
& 20 & 19,1 \\
& 10 & 17,1 \\
& 5 & 15,6 \\
\hline
\end{tabular}

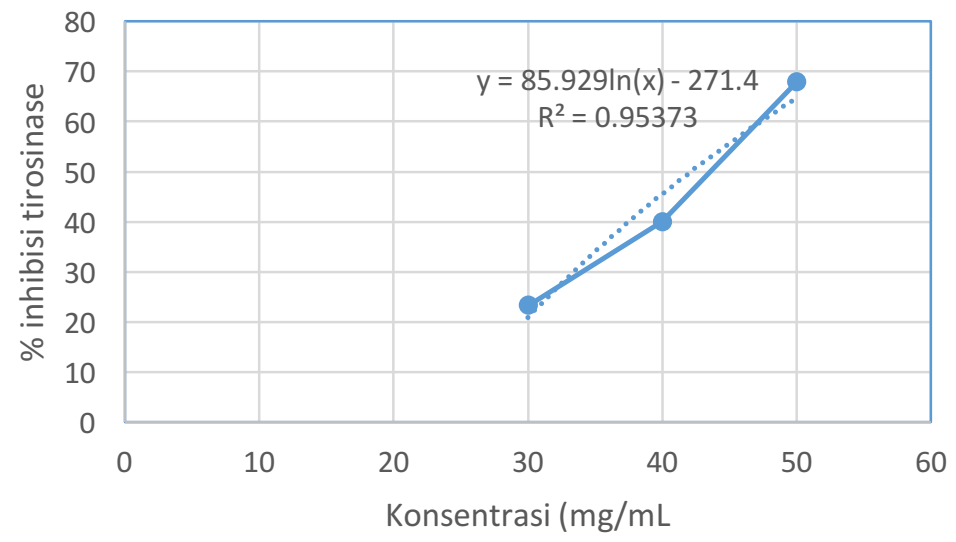

Gambar 2. Kurva hubungan antara konsentrasi $(\mathrm{mg} / \mathrm{mL})$ Ekstrak kulit jeruk terhadap persentase inhibisi

\section{Daftar Pustaka}

1. Hoogduijn MJ, Cemeli E, and Ross K. Melanin Protects Melanocytes And Keratinocytes Against H2O2-Induced
DNA Strand Breaks Through Its Ability To Bind Ca2+. Exp Cell Res. 2004; 294:60-67.

2. Costin, G. E., and Hearing, V. J. Human Skin Pigmentation: 
Melanocytes Modulated Skin Color in Response to Stress. FASEB Journal. 2007; 21(4):976-94.

3. Chang, T.S. An updated review of tyrosinase inhibitor. International Journal of molecular Science. 2009;10(6): 2440-2475.

4. Yang, Chao-Hsun, Chang, N.F, Chen, Y.S., Lee, S.M, Lin, P.J, and Lin C.C. Comparative Study On The Photostability Of Arbutin And Deoxyarbutin: Sensitivity To Ultraviolet Radiation And Enhanceed Photostability By The Water-Solube Sunscreen, Benzophenone-4. Biosci Biotech Biochem. 2013; 77(5): 11271130.

5. Baumann, L., Saghari, S. 2009a. Photoaging. In: Baumann, L., Saghari, S., Weisberg, E., editors. Cosmetic Dermatology. 2nd edition. New York: McGraw Hill. p 34-40.

6. Haryanto, S. Sehat dan Bugar Secara Alami. 2006. Jakarta: Penebar Plus. Hal 60.

7. Khasanah. 2014. Uji aktivitas antioksidan ekstrak etanolik kulit buah Jeruk nipis (citrus aurantifolia) dengan metode dpph (1,1-difenil-2pikrilhidrazil). Semarang: Fakultas Farmasi Universitas Wahid Hasyim Semarang.

8. Okwu. Citrus fruits: A rich source of phytochemicals and their roles inhuman health. Int $\mathrm{J}$ Chem Sci. 2008;6(2):451-471.

9. Dweck, A. 2008. Natural Ingredients Used in Cosmeceuticals. In: Walters, K.A., Roberts, M.S., editors. Dermatologic, Cosmeceutic, and
Cosmetic Development. New York: Informa Healthcare. p 306-312.

10. Baumann L. Allemann IB, Depigmentation agent. 2009b. In: Baumann L., Cosmetic dermatology: principles and practice, penyunting, Edisi ke-2, New York: Mc Graw Hill.

11. Abirami, A. 2014. In vitro antioxidant, anti-diabetic, cholinesterase and tyrosinase inhibitory potential of fresh juice from Citrus hystrix and $C$. maxima fruits. Bioresource Technology Lab. School of Life Sciences. Department of Environmental Sciences. Bharathiar University. Coimbatore 641046. Tamil Nadu. India.

12. Itoh, K., Hirata, N., Masuda, M., Naruto, S., Murata, K., Wakabayashi, K., Matsuda, H. Inhibitory effects of Citrus hassaku extract and its flavanone glycosides on melanogenesis. Biol Pharm Bull. 2009;32(3):410-415.

13. Sasaki K \& Yoshizaki F. Nobiletin as a tyrosinase inhibitor from the peel of citrus fruit. Biol Pharm Bull. 2002;25:806-808.

14. Voight, R. 1994. Buku Pelajaran Teknologi Farmasi. Edisi V: Diterjemahkan oleh Dr. Soendani Noerono. Yogyakarta :Gadjah Mada University press.

15. Batubara. Potency of Indonesia medical plants as tyrisinase inhibitors and antioxidant agent. Journal of Biologi Sciences. 2010;10: 138-144.

16. Arung. Screening of Indonesian plant for tyrosinase inhibitor activity. Journal Wood Science. 2006;51:520525. 